Article

\title{
Reaction kinetics and phase behavior in the chemoselective hydrogenation of 3-nitrostyrene over Co-N-C single-atom catalyst in compressed $\mathrm{CO}_{2}$
}

\author{
Dan Zhou a,b, Leilei Zhang b,\$, Wengang Liu b, Gang Xu b, Ji Yang b, Qike Jiang c, Aiqin Wang b,*, \\ Jianzhong Yin a,\# \\ a School of Chemical Engineering, State Key Laboratory of Fine Chemicals, Dalian University of Technology, Dalian 116024, Liaoning, China \\ b State Key Laboratory of Catalysis, Dalian Institute of Chemical Physics, Chinese Academy of Sciences, Dalian 116023, Liaoning, China \\ ' Dalian National Laboratory for Clean Energy, Dalian Institute of Chemical Physics, Chinese Academy of Sciences, Dalian 116023, Liaoning, China
}

\section{A R T I C L E I N F O}

\section{Article history:}

Received 14 January 2021

Accepted 8 February 2021

Available online 5 May 2021

\section{Keywords:}

Single-atom catalyst

Co-N-C

$\mathrm{CO}_{2}$

Phase behavior

Chemoselective hydrogenation

3-Nitrostyrene

\begin{abstract}
A B S T R A C T
Single-atom catalysts (SACs) have demonstrated excellent performances in chemoselective hydrogenation reactions. However, the employment of precious metals and/or organic solvents compromises their sustainability. Herein, we for the first time report the chemoselective hydrogenation of 3-nitrostyrene over noble-metal-free Co-N-C SAC in green solvent - compressed $\mathrm{CO}_{2}$. An interesting inverted $\mathrm{V}$-curve relation is observed between the catalytic activity and $\mathrm{CO}_{2}$ pressure, where the conversion of 3-nitrostyrene reaches the maximum of $100 \%$ at $5.0 \mathrm{MPa} \mathrm{CO}_{2}$ (total pressure of 8.1 MPa). Meanwhile, the selectivities to 3-vinylaniline at all pressures remain high (>99\%). Phase behavior studies reveal that, in sharp contrast with the single phase which is formed at total pressure above $10.8 \mathrm{MPa}$, bi-phase composed of $\mathrm{CO}_{2} / \mathrm{H}_{2}$ gas-rich phase and $\mathrm{CO}_{2}$-expanded substrate liquid phase forms at total pressure of $8.1 \mathrm{MPa}$, which dramatically changes the reaction kinetics of the catalytic system. The reaction order with respect to $\mathrm{H}_{2}$ pressure decreases from $\sim 0.5$ to zero at total pressure of $8.1 \mathrm{MPa}$, suggesting the dissolved $\mathrm{CO}_{2}$ in 3-nitrostyrene greatly promotes the dissolution of $\mathrm{H}_{2}$ in the substrate, which is responsible for the high catalytic activity at the peak of the inverted V-curve.
\end{abstract}

(C) 2021, Dalian Institute of Chemical Physics, Chinese Academy of Sciences. Published by Elsevier B.V. All rights reserved.

\section{Introduction}

With an output of 4 million tons per year, functionalized anilines represent key intermediates for the production of dyes, agrochemicals, pharmaceuticals, polymers and various other fine chemicals $[1,2]$. Traditionally, functionalized anilines are synthesized by non-catalytic reduction of their corresponding nitroarenes using stoichiometric reagents such as sodium hydrosulfite, iron, tin, or zinc [3]. However, this process has been prohibited due to serious environmental concerns. Among the environmentally benign approaches developed thus far, the catalytic hydrogenation by supported metal nanoparticles is the preferred one since $\mathrm{H}_{2}$ is a green and cost-effective reducing reagent and the only by-product is $\mathrm{H}_{2} \mathrm{O}$. This methodology

\footnotetext{
* Corresponding author. Tel/Fax: +86-411-84379348; E-mail: aqwang@dicp.ac.cn

\# Corresponding author. E-mail: jzyin@dlut.edu.cn

$\$$ Corresponding author. E-mail: zhangleilei@dicp.ac.cn

This work was supported by the National Key R\&D Program of China (2020YFA0710202), the National Science Foundation of China (21690080, 21690084, 21673228, 21721004), the Strategic Priority Research Program of the Chinese Academy of Sciences (XDB17020100).

DOI: 10.1016/S1872-2067(20)63785-8 | http://www.sciencedirect.com/journal/chinese-journal-of-catalysis | Chin. J. Catal., Vol. 42, No. 9, September 2021
} 
works well for simple nitroarenes, yet encounters problems for those with diverse reducible functional groups on the benzene ring because of the over-hydrogenation side-reactions, especially for nitrostyrenes where the $-\mathrm{C}=\mathrm{C}$ group is much more sensitive than $-\mathrm{NO}_{2}$. Generally, most of the nano-catalysts exhibit poor chemoselectivity [4], and only when those catalysts are modified by organic molecules (e.g., $\mathrm{Pt} / \mathrm{TiO}_{2}$-thiols [5]), or metal salts (such as $\mathrm{Pt} / \mathrm{C}-\mathrm{H}_{3} \mathrm{PO}_{2}-\mathrm{VO}$ (acac), $\left.\mathrm{Pt}-\mathrm{Pb} / \mathrm{CaCO}_{3}-\mathrm{FeCl}_{2}-n-\mathrm{Bu}_{4} \mathrm{NCl}, \mathrm{Rh} / \mathrm{C}-\mathrm{Fe}(\mathrm{OAc})_{2}\right)[6,7]$, could high chemoselectivity be achieved. However, these modifications by soluble reagents bring about additional environmental problems associated with the production of waste water.

Great efforts have been devoted to developing true heterogeneous and selective catalysts for the hydrogenation of functionalized nitroarenes [8,9]. Au nanoparticles supported on $\mathrm{Fe}_{2} \mathrm{O}_{3}$ [10], as well as modified $\mathrm{Pt}, \mathrm{Ru}$ and $\mathrm{Ni}$ nano-catalysts through strong metal-support interaction (SMSI) were reported to be highly selective for the hydrogenation of 3-nitrostyrene [11-17]. However, the catalytic activity was still not satisfactory enough due to either the low intrinsic capability of IB metals for activating $\mathrm{H}_{2}$ [18], or the decreased number of active sites for platinum-group metals resulting from the covering by the support or catalytically inert metals. To improve the catalytic efficiency, we previously developed $\mathrm{FeO}_{x}$-supported platinum single-atom and pseudo-single-atom as catalysts for the hydrogenation of 3-nitrostyrene, and a TOF as high as $11064 \mathrm{~h}^{-1}$ was achieved [19], which was 20-fold higher than the nano-particulate counterpart $\left(\mathrm{Pt} / \mathrm{TiO}_{2}\right.$, the best catalyst reported before our $\mathrm{Pt}_{1} / \mathrm{FeO}_{x}$ SACs) developed by Corma's group [12]. In addition, the selectivity to 3-vinylaniline reached as high as $\sim 99 \%$, far superior to the NPs counterpart. Recently, the catalytic activity of $\mathrm{Pt}_{1} / \mathrm{FeO}_{x}$ was further enhanced by 2 -fold through engineering the coordination environment of $\mathrm{Pt}$ single atoms while the chemoselectivity remained at 98\% [20], demonstrating the unrivalled capability of SACs for chemoselective hydrogenations [21-23]. Based on these achievements, we became interested in developing non-precious metal SACs for the hydrogenation of nitroarenes given the high price and limited availability of noble metals. Previously, we reported that single-atom catalyst Co-N-C demonstrated good catalytic performance in the hydrogenative coupling of nitroarenes to produce azo compounds with the assistance of $\mathrm{NaOH}$ [24]. Compared with the Co-based nano-catalysts reported (e.g., $\mathrm{Co}_{3} \mathrm{O}_{4} @ \mathrm{~N}-\mathrm{C}$ ) [25], our Co-N-C SAC bear the merits of mild reaction conditions (e.g., reaction temperature $110{ }^{\circ} \mathrm{C}$ vs $80{ }^{\circ} \mathrm{C}$ ). However, the addition of $\mathrm{NaOH}$ caused additional environmental concerns. Therefore, it is highly desirable to develop noble-metal-free and additive-free single-atom catalytic system for the hydrogenation of functionalized nitroarenes.

In fact, from the viewpoint of green chemistry, the use of organic solvents represents a critical concern in most of organic transformations. Solvents not only subtly affects the activity and selectivity of catalysts, but also accounts for the vast majority of chemical waste [26]. In the catalytic systems reported for hydrogenation of nitroarenes, toxic and flammable organic solvents (such as toluene, THF) have been widely employed, which will definitely not recommended by green chemistry. Therefore, it is highly desirable to substitute them with greener ones (such as ionic liquid, supercritical fluids, and water). In particular, supercritical $\mathrm{CO}_{2}\left(\mathrm{scCO}_{2}\right)$ offers prominent advantages such as nontoxicity, non-flammability, and facile regulation of phase behavior which improves the solubility of $\mathrm{H}_{2}$ and facilitates the separation of the products. Previously, Arai's group investigated the hydrogenation of nitrostyrene in $\mathrm{CO}_{2}$-expanded liquids with or without extra organic solvents (e.g., ethanol, toluene) $[27,28]$. However, the conversion (64\%) and selectivity to vinylaniline (75\%) were not satisfactory owing to the low-efficiency of $\mathrm{Pt} / \mathrm{TiO}_{2}$ nano-catalysts. By contrast, we achieved high conversion and selectivity (both were higher than 95\%) using $\mathrm{Pt}_{1} / \mathrm{FeO}_{x} \mathrm{SAC}$ for the reaction in $\mathrm{CO}_{2}$-expanded toluene [29], demonstrating the great power of single-atom catalyst in conjunction with green solvents. Even though, toluene was still indispensable to maintain high conversion level in that work.

In the present work, we have reported the hydrogenation of 3-nitrostyrene in compressed $\mathrm{CO}_{2}$ without any extra solvent over single-atom Co-N-C catalyst. An interesting inverted $\mathrm{V}$-curve relation was found between the hydrogenation activity and the $\mathrm{CO}_{2}$ pressure. Under optimal reaction conditions $\left(60^{\circ} \mathrm{C}\right.$, $\left.3 \mathrm{MPa} \mathrm{H}_{2}(\mathrm{RT}), 5.0 \mathrm{MPa} \mathrm{CO}_{2}\right), \mathrm{CO}_{2} / \mathrm{H}_{2}$ gaseous phase and $\mathrm{CO}_{2}$-expanded 3-nitrostyrene liquid phase formed in the top and bottom of the reactor, respectively. The biphasic system not only greatly enhanced the solubility of hydrogen in the $\mathrm{CO}_{2}$-expanded substrate liquid phase, but also changed the reaction order from 0.5 to zero with respect to hydrogen. Consequently, the reaction rate was dramatically increased. Our work has demonstrated a green, efficient and cost-effective route to the synthesis of functionalized anilines by combining the compressed $\mathrm{CO}_{2}$ solvent with the noble-metal-free single-atom catalyst.

\section{Experimental}

\subsection{Preparation of $\mathrm{Co}-\mathrm{N}-\mathrm{C}$}

The catalyst was prepared according to the procedure we previously reported [24]. Briefly, Cobalt (II) acetate tetrahydrate $(0.5 \mathrm{mmol}, 125 \mathrm{mg}), 1,10$-phenanthroline hydrate $(1.5$ mmol, $300 \mathrm{mg}$ ) and ethanol $(50 \mathrm{~mL})$ were added to a round bottom flask. The mixture was stirred for $0.5 \mathrm{~h}$ at room temperature, followed by addition of $4.0 \mathrm{~g} \mathrm{Mg}(\mathrm{OH})_{2}$ and refluxing at $60^{\circ} \mathrm{C}$ for $4 \mathrm{~h}$. After ethanol was removed by rotary evaporation, the remaining solid was dried at $60{ }^{\circ} \mathrm{C}$, and was subjected to pyrolysis at $700{ }^{\circ} \mathrm{C}$ for $2 \mathrm{~h}$ under $\mathrm{N}_{2}$ atmosphere $(100$ $\mathrm{mL} / \mathrm{min}$ ) with ramp rate of $2{ }^{\circ} \mathrm{C} / \mathrm{min}$. After $\mathrm{Mg}(\mathrm{OH})_{2}$ was removed by washing with $\mathrm{HCl}$ solution $(200 \mathrm{~mL}, 1 \mathrm{~mol} / \mathrm{L})$ twice, the remaining black solid was dried at $80{ }^{\circ} \mathrm{C}$, and was denoted as Co-N-C catalyst.

\subsection{Phase behaviour study}

The phase behaviour at various pressures and temperatures was visually observed by using a $29.3 \mathrm{~mL}$ high-pressure cell 
equipped with two quartz windows. After a certain amount of liquid substrate (3-nitrostyrene or nitrobenzene) and a stirring bar were introduced, the cell was sealed and purged for several times with $\mathrm{N}_{2}$. Then, hydrogen gas was introduced in the cell until the pressure reached $3 \mathrm{MPa}$. After the cell was heated to $60{ }^{\circ} \mathrm{C}$ with a heating jacket, the liquid $\mathrm{CO}_{2}$ was pumped into the cell until the designated pressure was reached. The gas-liquid mixture in the cell was stirred for a certain time and then left stand until steady state was achieved. At each pressure, the phase behaviour was visually observed, and a laser pen was used to check the occurrence of Tyndall effect.

\subsection{Hydrogenation reaction tests}

The hydrogenation reaction was conducted in a Parr autoclave $(25 \mathrm{~mL})$. In a typical reaction, $30 \mathrm{mg}$ catalyst, $0.5 \mathrm{mmol}$ 3-nitrostyrene, and $0.25 \mathrm{mmol} 0$-xylene (as an internal standard for GC analysis) were mixed and added into the autoclave before it was sealed. Then, the autoclave was purged with $\mathrm{N}_{2}$ for several times followed by being charged with $3 \mathrm{MPa} \mathrm{H}_{2}$. Subsequently, $\mathrm{CO}_{2}$ was pumped into the autoclave until the designated pressure was reached. The autoclave was then heated to the reaction temperature of $60{ }^{\circ} \mathrm{C}$ in water bath meanwhile the mixture in the autoclave was stirred at a speed of $1200 \mathrm{rpm}$ for $8 \mathrm{~h}$. After the reaction, the autoclave was cooled in icy water and depressurized slowly. The recovered organic liquid was analysed by an Agilent 7890 GC equipped with HP-5 columns and flame ionization detector (FID).

For kinetic measurements, the conversions were controlled below $30 \%$ by varying the reaction time between $0.5 \sim 3 \mathrm{~h}$ to ensure the reaction proceeded in the kinetically controlled region. For the catalyst durability test, the catalyst was recovered by filtration from the reaction mixture. After rinsing by ethanol and drying, the catalyst was subjected to another batch of reaction.

\subsection{Vapour-liquid equlibrium calculation}

The gas-liquid equilibrium phase compositions were calculated based on Peng-Robinson equation of state (PR EOS). $\mathrm{CO}_{2}-\mathrm{H}_{2}$ binary interaction parameters were obtained by fitting experimental vapour liquid equation data reported in [30], and $\mathrm{CO}_{2}$-nitrostyrene and $\mathrm{H}_{2}$-nitrostyrene binary interaction parameters were estimated through the group contribution method [31].

\section{Results and discussion}

\subsection{Determination of the dispersion of Co-species}

The single-atom Co-N-C catalyst was prepared by the method we reported previously [24]. The as-synthesized catalyst had a specific surface area of $649 \mathrm{~m}^{2} / \mathrm{g}$ and a cobalt loading of $4.2 \mathrm{wt} \%$. To determine the dispersion of Co-species, XRD and normal electron microscopy characterizations were first conducted. As shown in Fig. 1, XRD pattern did not show any diffraction peak due to metallic Co or cobalt oxides (Fig. 1(a)), which was in line with low-magnification TEM image where no any big $\mathrm{Co} / \mathrm{CoO}_{x}$ nanoparticles were observed (Fig. 1(b)), suggesting the high dispersion of Co-containing species. Subsequently, the sub-Ångström-resolution aberration-corrected high-angle annular dark field scanning transmission electron microscopy (HAADF-STEM) technique was employed to probe the Co-containing species. As expected, a large number of uniformly dispersed Co single atoms were clearly observed in the image (Fig. 1(c)), and there was no tiny $\mathrm{Co} / \mathrm{CoO}_{x}$ clusters by examination of different regions, demonstrating the single-atom dispersion of cobalt, in good agreement with our previous work [24].

\subsection{Effect of $\mathrm{H}_{2}$ pressure}

Having successfully prepared Co-N-C SACs, we then investigated their catalytic performance in the hydrogenation of 3-nitrostyrene in compressed $\mathrm{CO}_{2}$ medium. Besides the substrate and the internal standard for GC analysis, no extra organic solvent or additive was added for the consideration of environmentally benign process. The influence of $\mathrm{H}_{2}$ pressure on the catalytic efficiency was first studied, and the total pressure was maintained at about 9.2 MPa. As shown in Fig. 2(a), with an increase of $\mathrm{H}_{2}$ pressure from 1 to 3 and $5 \mathrm{MPa}$, the conversion of 3-nitrostyrene increased rapidly from 32\% to $84.7 \%$ and then to $100 \%$, which could be attributed to the increased solubility of $\mathrm{H}_{2}$ in the substrate and compressed $\mathrm{CO}_{2}$. To our delight, the selectivity to 3-vinylaniline was always kept at $100 \%$ even at full conversion, demonstrating the unique advantage of single-atom catalyst in delivering the chemoselective transformations.

\subsection{Influence of reaction temperature}

The dissolving ability of compressed $\mathrm{CO}_{2}$ is strongly affected by its density, which can be modulated by both temperature
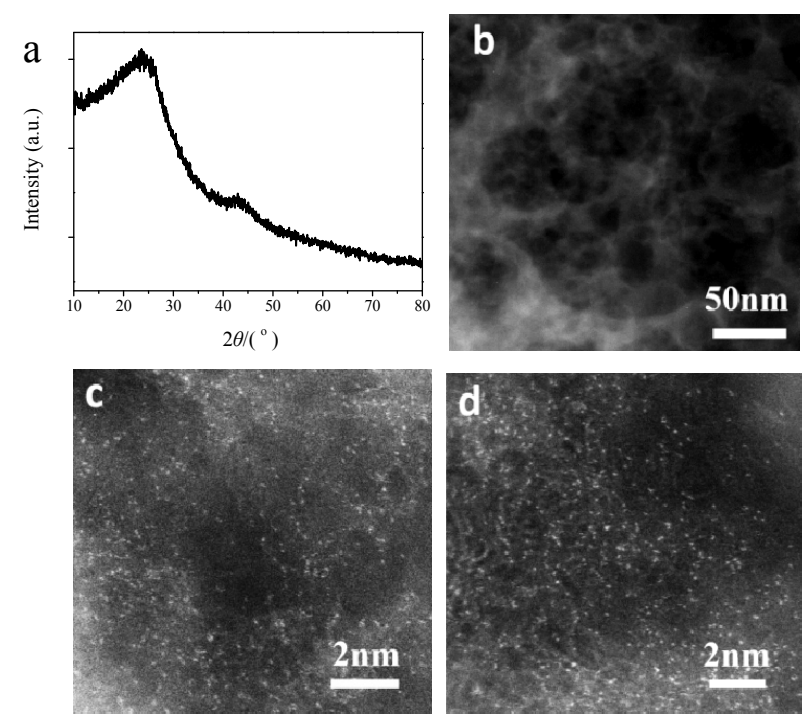

Fig. 1. XRD pattern (a), low-magnification STEM (b) and high-resolution HAADF-STEM images (c) of the as-synthesized Co-N-C catalyst; HAADF-STEM image of the spent Co-N-C catalyst (d). 

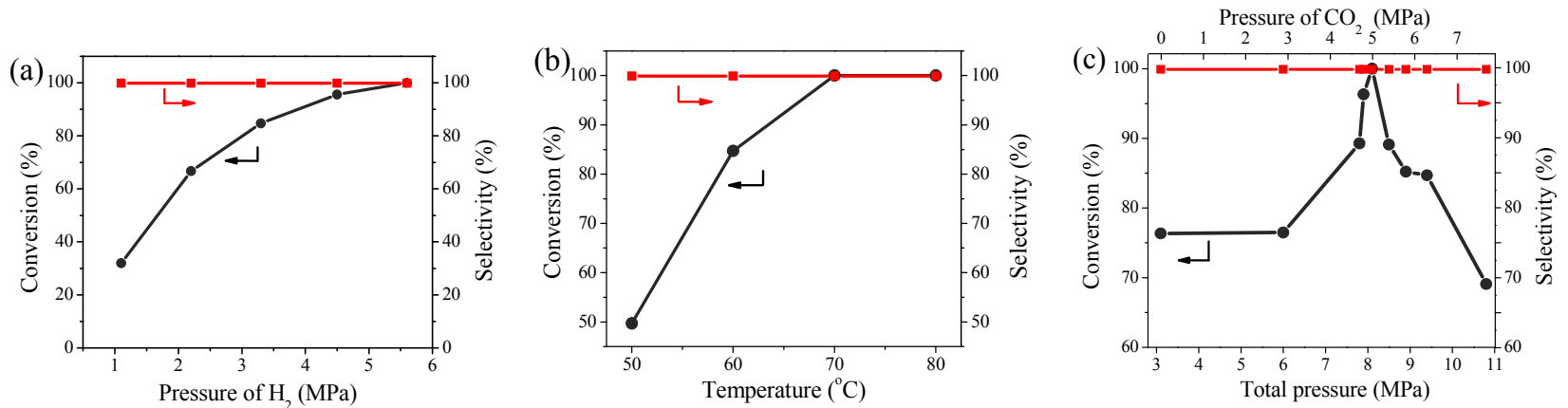

Fig. 2. The dependence of conversion and selectivity on $\mathrm{H}_{2}$ pressure (a), temperature (b) and $\mathrm{CO}_{2}$ pressure (c). Reaction conditions: 0.5 mmol 3-nitrostyrene, $30 \mathrm{mg}$ Co-N-C catalyst, $60^{\circ} \mathrm{C}(\mathrm{a}, \mathrm{c}), 3 \mathrm{MPa} \mathrm{H}_{2}(\mathrm{RT})(\mathrm{b}, \mathrm{c})$, total pressure: $9.2 \mathrm{MPa}(\mathrm{a}, \mathrm{b}), 8 \mathrm{~h}$.

and pressure [32]. Accordingly, the influence of temperature on the catalytic performance was investigated. As shown in Fig. 2(b), the 3-nitrostyrene conversion increased rapidly with the reaction temperature and reached $100 \%$ at $\mathrm{T} \geq 70{ }^{\circ} \mathrm{C}$. Meanwhile, the selectivity to 3 -vinylaniline was maintained $>99 \%$. Even when the temperature was $80^{\circ} \mathrm{C}$, no byproduct due to over-hydrogenation was detected, suggesting the Co-N-C SAC was chemically inert for the hydrogenation of $\mathrm{C}=\mathrm{C}$ bond as demonstrated by FTIR measurement and control experiment results we previously reported [24].

\subsection{Influence of system pressure}

As the system pressure had great impact on the phase behaviour, the dependence of catalytic performance on the total pressure was also studied, and the reaction temperature and $\mathrm{H}_{2}$ pressure were fixed at $60{ }^{\circ} \mathrm{C}$ and $3 \mathrm{MPa}$ (RT), respectively. As shown in Fig. 2(c), an inverted V-curve relation between the 3-nitrostyrene conversion and the $\mathrm{CO}_{2}$ pressure (as well as the total pressure) was observed. When no $\mathrm{CO}_{2}$ was charged into the reaction system (i.e., solvent free conditions), the 3-nitrostyrene conversion was only $76.3 \%$. With the introduction of $\mathrm{CO}_{2}$ and the increase of the total pressure from 3.1 to 8.1 $\mathrm{MPa}$ (corresponding to $\mathrm{CO}_{2}$ pressure of $5.0 \mathrm{MPa}$ ), the 3-nitrostyrene conversion increased greatly from $76 \%$ to $100 \%$. However, with further increase of total pressure above 8.1 $\mathrm{MPa}$, the conversion dropped dramatically and down to only $69.1 \%$ at total pressure of $10.8 \mathrm{MPa}$. Again, in all cases the chemoselectivity to 3-vinylaniline was maintained high at > $99 \%$, indicating that no over-hydrogenation side-reaction occurred on the single-atom Co-N-C catalyst.

The inverted V-curve relation between catalytic activity and total pressure as well as $\mathrm{CO}_{2}$ pressure was in sharp contrast with our previous work where the conversion of 3-nitrostyrene over $\mathrm{Pt}_{1} / \mathrm{FeO}_{x} \mathrm{SAC}$ increased monotonically with the pressure of $\mathrm{CO}_{2}$ [29]. It is known that the solubility of 3-nitrostyrene in $\mathrm{ScCO}_{2}$ decreases with the increase of temperature but increases with the pressure of $\mathrm{CO}_{2}$. In the $\mathrm{Pt}_{1} / \mathrm{FeO}_{x}$ catalytic system, most of the charged $0.5 \mathrm{mmol} 3$-nitrostyrene could be dissolved in $\mathrm{scCO}_{2}$ when the pressure was higher than $10.3 \mathrm{MPa}$ at $50{ }^{\circ} \mathrm{C}$ [29]. However, in the present work, the total pressure was lower $(8.1 \mathrm{MPa})$ yet the reaction temperature $\left(60^{\circ} \mathrm{C}\right)$ was higher than that in the $\mathrm{Pt}_{1} / \mathrm{FeO}_{x}$ catalytic system, therefore, 3 -nitrostyrene $(0.5 \mathrm{mmol})$ may not be completely dissolved in $\mathrm{CO}_{2}$, and therefore biphasic system might be formed.

To approve the formation of biphase, the phase behavior of 3-nitrostyrene- $\mathrm{CO}_{2}-\mathrm{H}_{2}$ ternary system was investigated by a high pressure view cell. Figs. 3(a), 3(e), and 3(i) displayed the images of 3-nitrostyrene in the absence of $\mathrm{CO}_{2}$, which clearly showed a pure liquid phase. When $\mathrm{CO}_{2}$ was charged and the total pressure reached $8.1 \mathrm{MPa}$, however, a quite different phase phenomenon was observed, and the appearance of a clear interface indicates the formation of biphase. The upper phase looked light cloudy and showed a strong Tyndall effect (Figs. 3(b) and (f)), which was indicative of the formation of $\mathrm{CO}_{2} / \mathrm{H}_{2}$ gas-rich phase where small droplets of the 3-nitrostyrene were dispersed. Meanwhile, the liquid substrate could be observed in the bottom of the cell, indicating the lower part was a 3-nitrostyrene-rich liquid phase (Fig. 3(j)) in which both $\mathrm{CO}_{2}$ and $\mathrm{H}_{2}$ were dissolved. Clearly, biphasic system was formed at this stage. Based on these observations, we propose that at the total pressure of $\sim 8 \mathrm{MPa}$ (the corresponding $\mathrm{CO}_{2}$

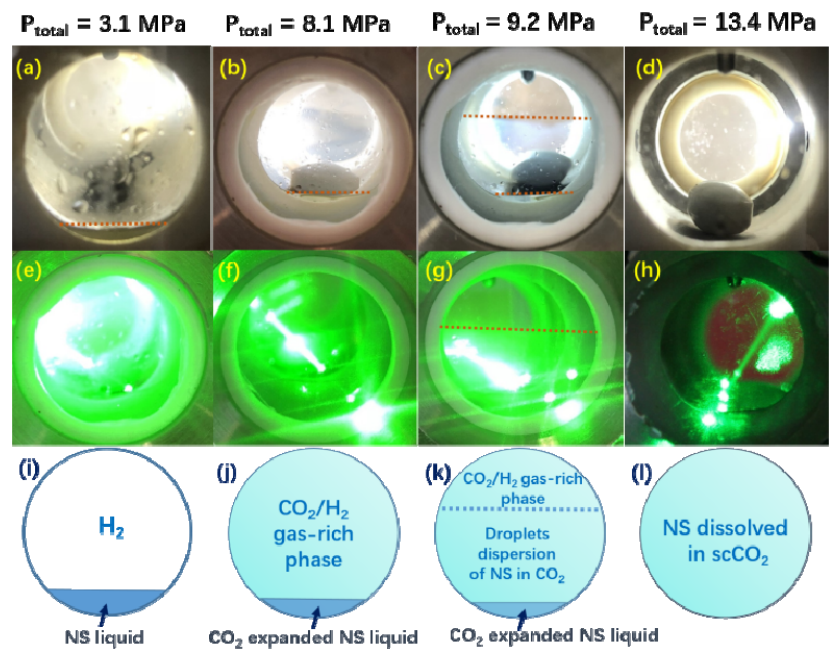

Fig. 3. Phase behaviour of 3-nitrostyrene (NS)- $\mathrm{CO}_{2}-\mathrm{H}_{2}$ ternary system: $(\mathrm{a}-\mathrm{d})$ visual observations, $(\mathrm{e}-\mathrm{h})$ images of the phase conditions when the view cell was irradiated by a laser beam, and (i-l) the corresponding illustration of the phases at the total pressure of $3.1 \mathrm{MPa}\left(\mathrm{CO}_{2}\right.$-free $)$, 8.1, 9.2 and $13.4 \mathrm{MPa}$, respectively. Other conditions: $0.5 \mathrm{mmol}$ 3-nitrostyrene, $3 \mathrm{MPa} \mathrm{H}_{2}$ (RT), $60^{\circ} \mathrm{C}$. 
pressure of $\sim 5 \mathrm{MPa}$ ), a part of $\mathrm{CO}_{2}$ is dissolved in the substrate and facilitates the dissolution of $\mathrm{H}_{2}$, similar to what had been reported earlier that $\mathrm{CO}_{2}$ could be dissolved into organic solvent to form $\mathrm{CO}_{2}$-expanded liquid [33]. The fact that no obvious expansion of the 3-nitrostyrene volume was observed at this stage was probably due to the small dosage of the 3-nitrostyrene (0.5 mmol) [34]. When the total pressure was further increased to $9.2 \mathrm{MPa}$, a dense cloudy phase was observed between the upper gaseous and bottom liquid phases, which presented a thick and diverging light column upon being irradiated by a laser beam (Figs. 3(c) and (g)), suggesting emulsive dispersion of 3-nitrostyrene in $\mathrm{CO}_{2}$ (Fig. 3(k)). Finally, when the total pressure reached 13.4 MPa, a single transparent phase formed without any interface, indicating the complete dissolution of 3-nitrostyrene in $\mathrm{scCO}_{2}$ (Figs. 3(d), (h) and (l)).

It was earlier reported that the volume expansion became significant and continuum of $\mathrm{CO}_{2}$-expanded solvent was formed when the organic solvent accounted for at least $20 \mathrm{~mol} \%$ $[34,35]$. Thereby, to further verify the volume expansion with increasing $\mathrm{CO}_{2}$ pressure, $6 \mathrm{~mL}$ of nitrobenzene was added into the view cell and the phase behaviour of $\mathrm{CO}_{2}$-nitrobenzene binary system was investigated. As shown in Fig. 4, the liquid level rose gradually with an increase of $\mathrm{CO}_{2}$ pressure, indicating that $\mathrm{CO}_{2}$ was dissolved into nitrobenzene and consequently caused the liquid volume expansion. More interesting, when $\mathrm{CO}_{2}$ pressure arrived at $5.14 \mathrm{MPa}, \mathrm{CO}_{2}$ started to penetrate quickly into nitrobenzene at the gas-liquid interface and formed a dilute layer with lighter colour than the bulk, which was more obviously observed at $\mathrm{CO}_{2}$ pressure of $6.1 \mathrm{MPa}$. This phase change point was not only in coincidence with the biphase formation in the 3-nitrostyrene- $\mathrm{CO}_{2}-\mathrm{H}_{2}$ ternary system (Fig. 3(b), (f), (g)), but also consistent with the peak conversion of 3-nitrostyrene in Fig. 2(c), thus strongly suggests that at this turning point the concentrations of $\mathrm{H}_{2}$ and substrate 3-nitrostyrene at the catalyst surface may reach the maxima given that the $\mathrm{CO}_{2}$-expanded organic liquid phase improves the dissolution of $\mathrm{H}_{2}$ in 3-nitrostyrene liquid phase. With further increase of $\mathrm{CO}_{2}$ pressure from 5.14 to $6.95 \mathrm{MPa}$, the liquid was continuously expanded until the full volume of the cell at 6.95 MPa.

Considering that the dissolving capability of $\mathrm{ScCO}_{2}$ is closely related to its density, we also calculated the density of $\mathrm{CO}_{2}$ at 60 ${ }^{\circ} \mathrm{C}$ and different pressures. The results showed that the $\mathrm{CO}_{2}$ had densities of $0.0984,0.1308$, and $0.3165 \mathrm{~g} / \mathrm{mL}$ at $\mathrm{CO}_{2}$ pressure of 5.0, 6.2 and $10.4 \mathrm{MPa}$, respectively [36]. Accordingly, the amount of 3-nitrostyrene dissolved in $\mathrm{CO}_{2}$ will increase following the same order as $\mathrm{CO}_{2}$ density with the change of $\mathrm{CO}_{2}$ pres-

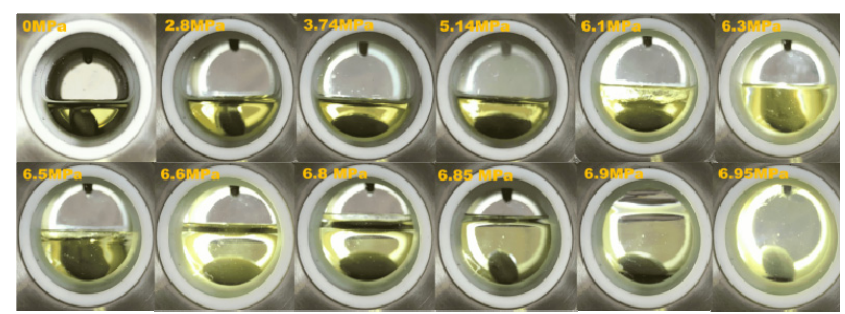

Fig. 4. Photographs of volume expansion in $\mathrm{CO}_{2}$-nitrobenzene binary system taken at $60^{\circ} \mathrm{C}$ under different pressures. sure: $5.0 \mathrm{MPa}<6.2 \mathrm{MPa}<10.4 \mathrm{MPa}$, and the concentration in the liquid phase containing catalyst will adversely decrease in this order. This can explain the descending trend of 3-nitrostyrene with the total pressure at the right side of Fig. 2(c) when the total pressure is higher than $8.1 \mathrm{MPa}$ (corresponding to $\mathrm{CO}_{2}$ partial pressure of $\sim 5 \mathrm{MPa}$ ).

To provide a more precise estimation of the hydrogen concentration in the liquid phase at different $\mathrm{CO}_{2}$ and $\mathrm{H}_{2}$ pressures, we calculated the solubility of $\mathrm{H}_{2}$ in the $\mathrm{CO}_{2}$-expanded 3-nitrostyrene substrate liquid phase at $60{ }^{\circ} \mathrm{C}$ based on the PR EOS, and the result is shown in Fig. 5. It can be seen that the solubility of $\mathrm{H}_{2}$ firstly increased with the $\mathrm{CO}_{2}$ pressure and reached maximum at about 5.0 MPa and then decreased rapidly at higher $\mathrm{CO}_{2}$ pressure. Such an inverted V-curve is well consistent with the activity curve with the $\mathrm{CO}_{2}$ pressure (Fig. 2(c)), and also agrees well with the report of Devetta et al. [37], implying that the solubility of $\mathrm{H}_{2}$ in the $\mathrm{CO}_{2}$-expanded liquid phase is a main factor determining the reaction rate.

To further clarify the impact of $\mathrm{CO}_{2}$ pressure (as well as total pressure) on the reaction rate, we performed kinetic studies, and the results are summarized in Figs. 6 and 7 as well as Tables S1-S5. The reaction orders with respect to 3-nitrostyrene at total pressure of 8.1 and $11.2 \mathrm{MPa}$ were measured to be 0.7 and 0.8 , respectively, both of them were close to first-order dependence, indicating the adsorption/activation of 3-nitrostyrene was involved in the rate-determining step and was almost independent on the total pressure. On the other hand, as shown in Fig. 7, under conditions of $\mathrm{CO}_{2}$-free and total pressure of $11.2 \mathrm{MPa}$, the reaction orders with respect to $\mathrm{H}_{2}$ pressure were measured to be 0.4 and 0.6 , respectively, suggesting the heterolytic dissociation of $\mathrm{H}_{2}$ and the attack of $-\mathrm{NO}_{2}$ by proton was involved in the rate-determining step [38,39]. By contrast, at total pressure of $8.1 \mathrm{MPa}$ (corresponding to the $\mathrm{CO}_{2}$ partial pressure of $5.0 \mathrm{MPa}$ ), two-stage relations between $\ln \left(P_{\mathrm{H} 2}\right)$ and $\ln (r)$ were observed. That is, the reaction order with respect to $\mathrm{H}_{2}$ was 0.7 in the range of $1-2.5 \mathrm{MPa} \mathrm{H}_{2}$, whereas 0.06 when the pressure of $\mathrm{H}_{2}$ was 3-5 MPa. The nearly zero order at the total pressure of $8.1 \mathrm{MPa}$ suggested that the solubility of $\mathrm{H}_{2}$ in the liquid phase was greatly enhanced by the dissolved $\mathrm{CO}_{2}$ such that the catalyst surface was saturated with $\mathrm{H}_{2}$. Therefore, by changing the $\mathrm{CO}_{2}$ partial pressure at a fixed $\mathrm{H}_{2}$ pressure one can effectively tune the hydrogen solubility in the

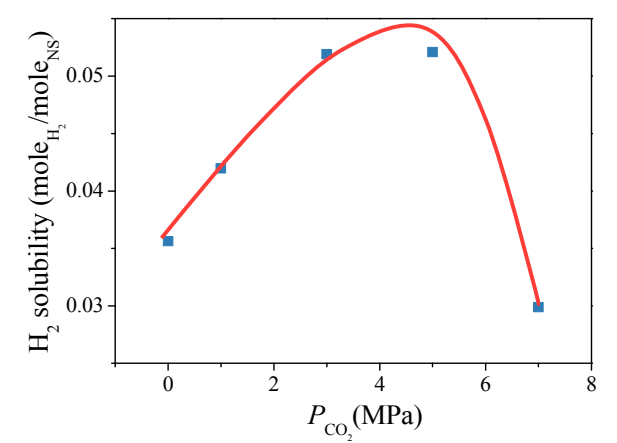

Fig. 5. Calculated $\mathrm{H}_{2}$ solubility in liquid substrate 3-nitrostyrene (NS) at $60^{\circ} \mathrm{C}$ under different $\mathrm{CO}_{2}$ pressures. 

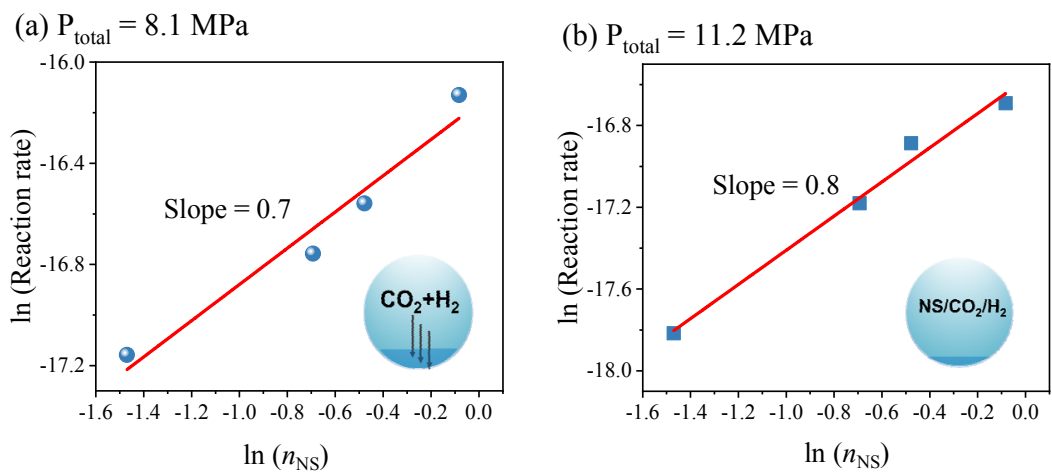

Fig. 6. The dependence of reaction rate on the concentration of 3-nitrostyrene at total pressure of 8.1 (a) and 11.2 (b) MPa. Reaction conditions: $P_{\text {total }}$ $=8.1 \mathrm{MPa}, P_{\mathrm{H} 2}=3.0 \mathrm{MPa}(\mathrm{RT}), 30 \mathrm{mg}$ catalyst, $60{ }^{\circ} \mathrm{C}$, reaction time was varied between $0.5-1 \mathrm{~h}$ to maintain the conversions below $30 \%$.
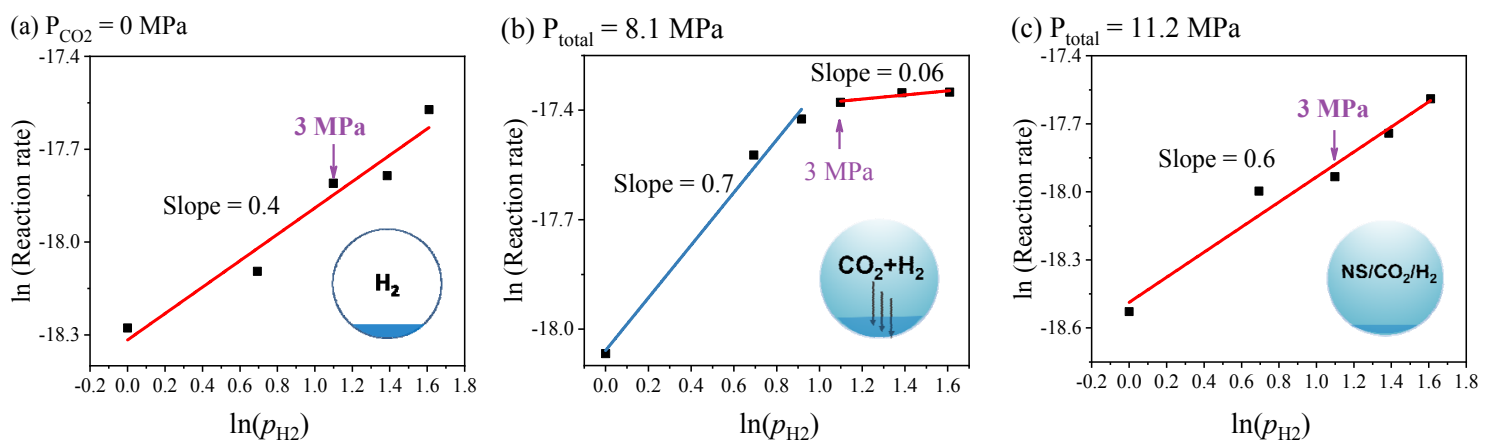

Fig. 7. The dependence of reaction rate on the pressure of $\mathrm{H}_{2}$ at (a) $\mathrm{CO}_{2}$-free condition; (b) total pressure of $8.1 \mathrm{MPa}$; (c) total pressure of $11.2 \mathrm{MPa}$. Reaction conditions: $0.5 \mathrm{mmol} 3-\mathrm{NS}, 0.25 \mathrm{mmol}$ o-xylene, $30 \mathrm{mg}$ catalyst, $60^{\circ} \mathrm{C}$, and the reaction time was varied between $1-3 \mathrm{~h}$ to maintain the conversion below $30 \%$.

$\mathrm{CO}_{2}$-expanded liquid phase, and consequently change the reaction kinetics towards high catalytic efficiency over the single-atom catalyst.

Taken together, the $\mathrm{CO}_{2}$ pressure influenced the phase behaviour and consequently the kinetics of the single-atom Co-N-C catalytic system, which made $\mathrm{CO}_{2}$ expanded substrate liquid rather than the single gaseous phase be the most effective medium for the hydrogenation of 3-nitrostyrene. Similarly, Arai's group reported expanded liquid substrate phase was effective medium for the hydrogenation of cinnamaldehyde to cinnamyl alcohol [40]. The reason was also ascribed to the high concentration of cinnamaldehyde and $\mathrm{H}_{2}$, as well as decreased viscosity, however, no kinetic and phase behaviour studies were performed in that work. By contrast, in our previously reported $\mathrm{Pt}_{1} / \mathrm{FeO}_{x}$ system for the hydrogenation of 3 -nitrostyrene in $\mathrm{scCO}_{2}$, the ideal medium was a single gaseous phase (i.e., the substrate was completely dissolved in $\mathrm{scCO}_{2}$ ) [29]. The reason was ascribed to the increased solubility of $\mathrm{H}_{2}$ as well as the reduced viscosity that facilitated the mass transfer of reactants.

\subsection{Durability of Co-N-C catalyst}

Catalyst durability is one of the most important concerns for practical utilization. After the reaction, the Co-N-C single-atom catalyst could be easily recovered from the reaction mixture by filtration or centrifugation, and was subjected to another batch of reaction without additional treatment. As shown in Fig. 8, the catalyst could be recycled for at least 4 times without obvious decay in either catalytic activity or chemo-selectivity. HAADF-STEM image of the recovered catalyst showed that cobalt still existed as single atoms without any aggregation (Fig. $1(d)$ ), demonstrating the high stability of the single-atom Co-N-C catalysts.

\section{Conclusions}

In summary, compressed $\mathrm{CO}_{2}$ was explored as environmentally benign medium for the chemoselective hydrogenation of

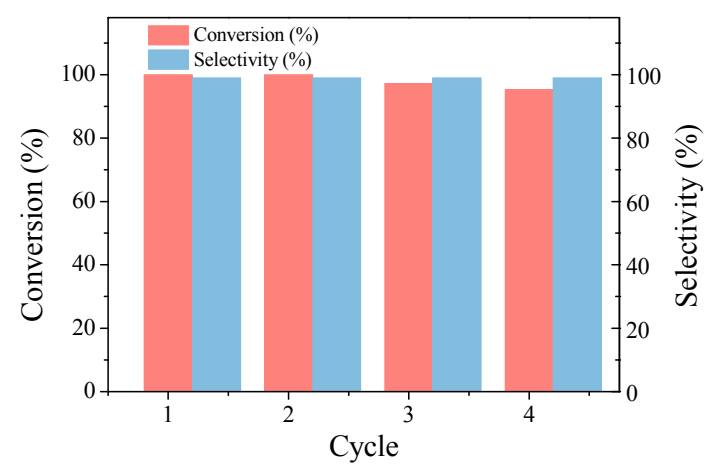

Fig. 8. Durability of the Co-N-C catalyst. Condition: 3-nitrostyrene $(0.5$ $\mathrm{mmol}), \mathrm{Co}-\mathrm{N}-\mathrm{C}$ catalysts $(30 \mathrm{mg})$, o-xylene $(0.25 \mathrm{mmol}$, as the internal standard), $60{ }^{\circ} \mathrm{C}$, total pressure of $8.1 \mathrm{MPa}$ and $\mathrm{H}_{2}$ pressure of $3.0 \mathrm{MPa}$ (RT), $8 \mathrm{~h}$. 
3-nitrostyrene over single-atom Co-N-C catalyst. An inverted $\mathrm{V}$-curve relation was found between the catalytic activity and the total pressure (or $\mathrm{CO}_{2}$ pressure), with the conversion peak $(100 \%)$ being attained at the total pressure of $8.1 \mathrm{MPa}$ (corresponding $\mathrm{CO}_{2}$ pressure of $5.0 \mathrm{MPa}$ ). $\mathrm{CO}_{2}-\mathrm{H}_{2}$-nitrostyrene ternary system phase behaviour studies revealed that under the optimum total pressure of $8.1 \mathrm{MPa}$, biphasic system was formed where the upper part was $\mathrm{CO}_{2} / \mathrm{H}_{2}$ gas-rich phase and the lower part was $\mathrm{CO}_{2}$-expanded nitrostyrene liquid phase. The formation of $\mathrm{CO}_{2}$-expanded substrate liquid greatly increased the solubility of $\mathrm{H}_{2}$, changing the reaction order with respect to $\mathrm{H}_{2}$ from $\sim 0.5$ to nearly zero. The favourable reaction kinetics assisted by the compressed $\mathrm{CO}_{2}$ led to the complete conversion of 3-nitrostyrene at mild reaction temperature $(60$ ${ }^{\circ} \mathrm{C}$ ), and the single-atom dispersion of Co offered $>99 \%$ selectivity to 3-vinylaniline even at full conversions. In addition, the single-atom catalyst could be reused for 4 times without obvious decrease of conversion or chemoselectivity. Our work provides an alternative route to tuning the catalytic performance by jointly using green compressed $\mathrm{CO}_{2}$ and noble-metal-free single-atom catalysts.

\section{References}

[1] R. S. Downing, P. J. Kunkeler , H. van Bekkum, Catal. Today, 1997, 37, 121-136.

[2] H.-U. Blaser, Science, 2006, 313, 312-313.

[3] R. A. Sheldon, H. Van Bekkum, Fine Chemicals Through Heterogeneous Catalysis, John Wiley \& Sons, 2008.

[4] P. N. Rylander, Catalytic Hydrogenation in Organic Syntheses, Academic Press, New York, 1979.

[5] M. Makosch, W.-I. Lin, V. Bumbálek, J. Sá, J. W. Medlin, K. Hungerbühler, J. A. van Bokhoven, ACS Catal., 2012, 2, 2079-2081.

[6] A. Akao, K. Sato, N. Nonoyama, T. Mase, N. Yasuda, Tetrahedron Lett., 2006, 47, 969-972.

[7] M. J. Beier, J.-M. Andanson, A. Baiker, ACS Catal., 2012, 2, 2587-2595.

[8] L. Wang, E. Guan, J. Zhang, J. Yang, Y. Zhu, Y. Han, M. Yang, C. Cen, G. Fu, B. C. Gates, F.-S. Xiao, Nat. Commun., 2018, 9, 1362.

[9] S. Zhang, C.-R. Chang, Z.-Q. Huang, J. Li, Z. Wu, Y. Ma, Z. Zhang, Y.
Wang, Y. Qu, J. Am. Chem. Soc., 2016, 138, 2629-2637.

[10] A. Corma, P. Serna, Science, 2006, 313, 332-334.

[11] A. Yarulin, C. Berguerand, I. Yuranov, F. Cardenaslizana, I. Prokopyeva, L. Kiwiminsker, J. Catal., 2015, 321, 7-12.

[12] A. Corma, P. Serna, P. Concepción, J. J. Calvino, J. Am. Chem. Soc., 2008, 130, 8748-8753.

[13] M. Tamura, N. Yuasa, Y. Nakagawa, K. Tomishige, Chem. Commun., 2017, 53, 3377-3380.

[14] H. Wei, X. Wei, X. Yang, G. Yin, A. Wang, X. Liu, Y. Huang, T. Zhang, Chin. J. Catal., 2015, 36, 160-167.

[15] L. Wang, J. Zhang, H. Wang, Y. Shao, X. Liu, Y.-Q. Wang, J. P. Lewis, F.-S. Xiao, ACS Catal., 2016, 6, 4110-4116.

[16] K.-i. Shimizu, Y. Miyamoto, A. Satsuma, J. Catal., 2010, 270, 86-94.

[17] X. Liu, H.-Q. Li, S. Ye, Y.-M. Liu, H.-Y. He, Y. Cao, Angew. Chem. Int. Ed., 2014, 53, 7624-7628.

[18] H. Liu, M. Chai, G. Pei, X. Liu, L. Li, L. Kang, A. Wang, T. Zhang, Chin. J. Catal., 2020, 41, 1099-1108.

[19] L. Cao, W. Wang, Q. Jiang, C. Wang, M. Knossow, B. Gigant, Nat. Commun., 2014, 5, 5364.

[20] Y. Ren, Y. Tang, L. Zhang, X. Liu, L. Li, S. Miao, D. Sheng Su, A. Wang, J. Li, T. Zhang, Nat. Commun., 2019, 10, 4500.

[21] Z. Li, D. Wang, Y. Wu, Y. Li, Natl. Sci. Rev., 2018, 5, 673-689.

[22] F. Yang, M. Wang, W. Liu, B. Yang, Y. Wang, J. Luo, Y. Tang, L. Hou, Y. Li, Z. Li, B. Zhang, W. Yang, Y. Li, Green Chem., 2019, 21, 704-711.

[23] J. Zhang, Q.-A. Huang, J. Wang, J. Wang, J. Zhang, Y. Zhao, Chin. J. Catal., 2020, 41, 783-798.

[24] W. Liu, L. Zhang, W. Yan, X. Liu, X. Yang, S. Miao, W. Wang, A. Wang, T. Zhang, Chem. Sci., 2016, 7, 5758-5764.

[25] Z. Wei, J. Wang, S. Mao, D. Su, H. Jin, Y. Wang, F. Xu, H. Li, Y. Wang, ACS Catal., 2015, 5, 4783-4789.

[26] P. Anastas, N. Eghbali, Chem. Soc. Rev., 2010, 39, 301-312.

[27] S.-i. Fujita, H. Yoshida, K. Asai, X. Meng, M. Arai, J. Supercrit. Fluids, 2011, 60, 106-112.

[28] H. Yoshida, K. Kato, J. Wang, X. Meng, S. Narisawa, S.-i. Fujita, Z. Wu, F. Zhao, M. Arai, J. Phys. Chem. C, 2011, 115, 2257-2267.

[29] G. Xu, H. S. Wei, Y. J. Ren, J. Z. Yin, A. Q. Wang, T. Zhang, Green Chem., 2016, 18, 1332-1338.

[30] N. D. Evdokimenko, K. O. Kim, G. I. Kapustin, N. A. Davshan, A. L. Kustov, Catal. Ind., 2018, 10, 288-293.

[31] J.-N. Jaubert, F. Mutelet, Fluid Phase Equilib., 2004, 224, 285-304.

[32] F. Sahena, I. S. M. Zaidul, S. Jinap, A. A. Karim, K. A. Abbas, N. A. N.

\section{Graphical Abstract}

Chin. J. Catal., 2021, 42: 1617-1624 doi: 10.1016/S1872-2067(20)63785-8

\section{Reaction kinetics and phase behavior in the chemoselective hydrogenation of 3-nitrostyrene over Co-N-C single-atom catalyst in compressed $\mathrm{CO}_{2}$}

Dan Zhou, Leilei Zhang *, Wengang Liu, Gang Xu, Ji Yang, Qike Jiang, Aiqin Wang *, Jianzhong Yin *

Dalian University of Technology;

Dalian Institute of Chemical Physics, Chinese Academy of Sciences

An inverted V-curve relation was observed between conversion and $P_{\mathrm{CO} 2}$ in hydrogenation of 3-nitrostyrene over Co-N-C SACs in compressed $\mathrm{CO}_{2}$, where the peak was attributed to the enhanced solubility of $\mathrm{H}_{2}$ in $\mathrm{CO}_{2}$-expanded substrate liquid.

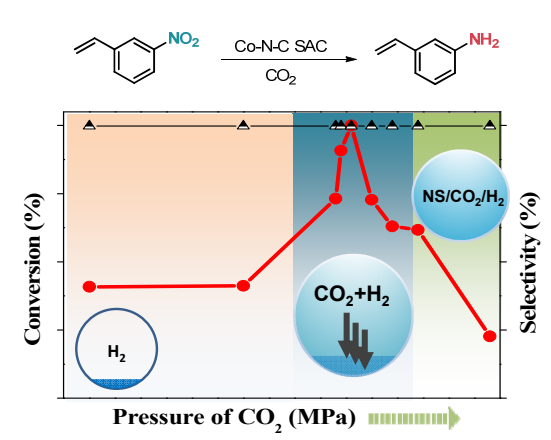


Norulaini, A. K. M. Omar, J. Food Eng., 2009, 95, 240-253.

[33] P. G. Jessop, B. Subramaniam, Chem. Rev., 2007, 107, 2666-2694.

[34] M. Wei, G. T. Musie, D. H. Busch, B. Subramaniam, J. Am. Chem. Soc., 2002, 124, 2513-2517.

[35] G. Musie, M. Wei, B. Subramaniam, D. H. Busch, Coord. Chem. Rev., 2001, 219-221, 789-820.

[36] R. Span, W. Wagner, J. Phys. Chem. Ref. Data, 1996, 25, 1509-1596.
[37] L. Devetta, A. Giovanzana, P. Canu, A. Bertucco, B. J. Minder, Catal. Today, 1999, 48, 337-345.

[38] K. Tomishige, Y. Nakagawa, M. Tamura, Green Chem., 2017, 19, 2876-2924.

[39] M. Zhou, M. Yang, X. Yang, X. Zhao, L. Sun, W. Deng, A. Wang, J. Li, T. Zhang, Chin. J. Catal., 2020, 41, 524-532.

[40] F. Zhao, S. Fujita, S. Akihara, M. Arai, J. Phys. Chem. A, 2005, 109, 4419-4424.

\title{
压缩 $\mathrm{CO}_{2}$ 中 $\mathrm{Co}-\mathrm{N}-\mathrm{C}$ 催化3-硝基苯乙烯选择性加氢反应动力学及相行为
}

\author{
周 丹 $^{\mathrm{a}, \mathrm{b}}$, 张䂞䂞 ${ }^{\mathrm{b}, \$}$, 刘文刚 ${ }^{\mathrm{b}}$, 徐 刚 $^{\mathrm{b}}$, 杨 级 ${ }^{\mathrm{b}}$, 蒋齐可 ${ }^{\mathrm{c}}$, 王爱琴 ${ }^{\mathrm{b},{ }^{*}}$, 银建中 ${ }^{\mathrm{a}, \text { \# }}$ \\ ${ }^{\mathrm{a}}$ 大连理工大学化工学院, 精细化工国家重点实验室, 辽宁大连 116024 \\ $\mathrm{b}^{\mathrm{b}}$ 中国科学院大连化学物理研究所, 催化基础国家重点实验室, 辽宁大连116023 \\ ${ }^{\mathrm{c}}$ 中国科学院大连化学物理研究所, 洁净能源国家实验室(筹), 辽宁大连 116023
}

\begin{abstract}
摘要: 对于苯环上含有各种可还原基团(如 $-\mathrm{C}=\mathrm{C},-\mathrm{CN},-\mathrm{C} \equiv \mathrm{C}$ )的硝基芳烃, 通过选择性加氢来制备芳香胺类化合物依然充 满挑战. 负载型纳米催化剂通常存在过度加氢的缺陷, 虽然通过覆盖部分金属位点等方法可改善其选择性, 但多是以牺牲 催化活性为代价. 得益于较高的原子利用率以及孤立的活性位结构, 单原子催化剂在硝基芳烃选择性加氢反应中轵露头 角. 例如 $\mathrm{Pt}_{1} / \mathrm{FeO}_{x}$ 单原子催化剂在3-硝基苯乙烯加氢反应中对目标产物的选择性高于 $99 \%$, 且转化频率( $\mathrm{TOF}$ )是 $\mathrm{Pt}$ 纳米催化 剂的 20 倍以上. 然而, 已报道的单原子催化体系中, 活性组分多为Pt族贵金属, 且以有机溶剂为反应介质, 不符合绿色化学 理念.
\end{abstract}

本文以环境友好型溶剂——压缩 $\mathrm{CO}_{2}$ 为反应介质, 以氮掺杂碳负载非贵金属 $\mathrm{Co}$ 单原子 $(\mathrm{Co}-\mathrm{N}-\mathrm{C})$ 为催化剂, 实现了 3 -硝 基苯乙烯的选择性加氢, 且反应体系中无任何有机溶剂和助剂. 在温和 $\left(60{ }^{\circ} \mathrm{C}, 3 \mathrm{MPa} \mathrm{H}_{2}(\mathrm{RT})\right.$, 总压 $\left.8.1 \mathrm{MPa}\right)$ 的反应条件下, 3-硝基苯乙烯可完全转化, 目标产物3-乙烯基苯胺的选择性达到> 99\%, 且产物可通过简单卸压直接分离. Co-N-C单原子 催化剂表现出较高的稳定性, 循环使用4次以后活性并无明显降低. HAADF-STEM表征发现反应后的催化剂中, Co仍然呈 单原子分散.

研究发现, 通过改变 $\mathrm{CO}_{2}$ 压力(即 $\mathrm{CO}_{2}$ 相行为)可调变 $\mathrm{H}_{2}$ 在其中的溶解度以及在加氢反应中的反应级数, 进而调变反应速 率. 通常认为, 催化活性会随 $\mathrm{CO}_{2}$ 压力增大呈线性增加, 而本文中转化率却随 $\mathrm{CO}_{2}$ 压力增加呈现“倒 $\mathrm{V}$ 型”曲线关系, 即当体 系总压为 $8.1 \mathrm{MPa}\left(P_{\mathrm{CO} 2}=5.0 \mathrm{MPa}\right)$ 时, 转化率达到最大值 $(100 \%)$, 而升高或降低 $\mathrm{CO}_{2}$ 压力均会显著降低催化活性.

为解释“倒 $\mathrm{V}$ 型”曲线的成因, 通过含可视窗的高压釜研究了 3-硝基苯乙烯 $/ \mathrm{CO}_{2} / \mathrm{H}_{2}$ 三元体系的相行为. 发现当总压为 13.4 MPa时, 体系为均匀的一相(即3-硝基苯乙烯完全溶解在 $\mathrm{CO}_{2}$ 中); 而当总压为 $8.1 \mathrm{MPa}$ 时, 却形成了气-液两相. 用激光 笔照射高压釜上部的气相时, 出现了明显的丁达尔现象, 说明其中溶解有少量的3-硝基苯乙烯, 呈胶体分散; 底部为 $\mathrm{CO}_{2}$ 膨 胀的3-硝基苯乙烯液相, 且该膨胀行为通过硝基苯- $\mathrm{CO}_{2}$ 二元相行为研究得到证实(即在一定 $\mathrm{CO}_{2}$ 压力下, $6 \mathrm{~mL}$ 硝基苯可被 $\mathrm{CO}_{2}$ 膨胀至充满整个高压釜(容积为 $29.3 \mathrm{~mL}$ )). 动力学研究发现, 在不含 $\mathrm{CO}_{2}$ 以及总压为 $11.2 \mathrm{MPa}$ 时, $\mathrm{H}_{2}$ 的反应级数为 $~ 0.5$; 而当总压为 $8.1 \mathrm{MPa}\left(\mathrm{CO}_{2}\right.$ 压力为 $\left.5.0 \mathrm{MPa}\right)$ 时, $\mathrm{H}_{2}$ 的级数降为 0 , 说明该压力下 $\mathrm{H}_{2}$ 的溶解度显著增加. 通过Peng-Robinson方程 计算了不同 $\mathrm{CO}_{2}$ 压力下 $\mathrm{H}_{2}$ 的溶解度, 发现 $\mathrm{H}_{2}$ 溶解度与 $\mathrm{CO}_{2}$ 压力也呈 “倒 $\mathrm{V}$ 型”曲线关系, 且最高点对应的 $\mathrm{CO}_{2}$ 压力与上述转化 率- $P_{\mathrm{CO} 2}$ 曲线一致. 因此, 当总压为 $8.1 \mathrm{MPa}, \mathrm{CO}_{2}$ 分压为 $5.0 \mathrm{MPa}$ 时形成了 $\mathrm{CO}_{2}$ 膨胀的3-硝基苯乙烯液体, 溶解入该膨胀液体 的 $\mathrm{CO}_{2}$ 促进了 $\mathrm{H}_{2}$ 的溶解, 进而使 $\mathrm{H}_{2}$ 的反应级数降为 0 , 从而促进了加氢反应的进行.

综上, 本文以压缩 $\mathrm{CO}_{2}$ 为溶剂, 以非贵金属基 $\mathrm{Co}-\mathrm{N}-\mathrm{C}$ 为催化剂, 发展了一种3-硝基苯乙烯绿色选择性加氢途径. 同时发 现, 改变 $\mathrm{CO}_{2}$ 压力可调变反应体系的相行为及反应动力学行为, 进而调变催化性能. 该研究结果可为调变压缩 $\mathrm{CO}_{2}$ 介质中进 行的其它催化转化反应性能提供借鉴.

关键词: 单原子催化剂; $\mathrm{Co}-\mathrm{N}-\mathrm{C} ; \mathrm{CO}_{2}$; 相行为; 化学选择性加氢; 3-硝基苯乙烯

收稿日期: 2021-01-14. 接受日期: 2021-02-08. 上网时间: 2021-05-05.

*通讯联系人. 电话/传真: (0411)84379348; 电子信箱: aqwang@dicp.ac.cn

\#通讯联系人. 电子信箱: jzyin@dlut.edu.cn

通讯联系人. 电子信箱: zhangleilei@dicp.ac.cn

基金来源：国家重点研发计划(2020YFA0710202); 国家自然科学基金(21690080, 21690084, 21673228, 21721004); 中国科学院战 略性先导科技专项(XDB17020100).

本文的电子版全文由Elsevier出版社在ScienceDirect上出版(http://www.sciencedirect.com/journal/chinese-journal-of-catalysis). 